\title{
Gelatin in replacement of bovine heart in feed training of Lophiosilurus alexandri in different water salinities
}

\author{
ANA LUCIA SALARO', JOSÉ C. OLIVEIRA JUNIOR' ${ }^{1}$, FREDERICO W. LIMA ${ }^{1}$, RENATO B. FERRAZ ${ }^{1}$, \\ MARCELO D. PONTES ${ }^{1}$, DANIEL A.V. CAMPELO ${ }^{1}$, JENER A.S. ZUANON ${ }^{1}$ and RONALD K. LUZ ${ }^{2}$ \\ ${ }^{1}$ Universidade Federal de Viçosa, Departamento de Biologia Animal, Av. P. H. Rolfs, s/n, 36570-900 Viçosa, MG, Brasil \\ ${ }^{2}$ Universidade Federal de Minas Gerais, Escola de Veterinária, Departamento de Zootecnia, Laboratório de \\ Aquacultura, Av. Presidente Antônio Carlos, 6627, Pampulha, 31270-901 Belo Horizonte, MG, Brasil
}

Manuscript received on October 28, 2014; accepted for publication on March 9, 2015

\begin{abstract}
The aim of this study was to evaluate commercial gelatin in the total replacement of bovine heart in feed training of "pacamã" Lophiosilurus alexandri in different water salinities. A completely randomized experimental design, in a $2 \times 3$ factorial arrangement, was performed using two types of moist ingredients (bovine heart and gelatin) and three water salinities $\left(0.0 ; 2.0\right.$ and $4.0 \mathrm{~g}$ of salt $\left.\mathrm{L}^{-1}\right)$ with three replications. Juveniles $(2.39 \pm 0.08 \mathrm{~cm}$ standard length and $0.20 \pm 0.03 \mathrm{~g}$ of weight) were conditioned to accept commercial diets by the technique of the gradual transition of ingredients. At the end of 36 days no differences were observed to weight gain, length gain and specific growth rate. The feed training efficiency was better $(\mathrm{P}<0.05)$ with the gelatin use, $100.0 \%$. There was a negative effect of salinity on the survival rate and management efficiency in the concentration of $4 \mathrm{~g}$ of salt $\mathrm{L}^{-1}$, with values of $58.6 \pm 12.0 \%$ and $58.0 \pm 12.0 \%$, respectively. Lophiosilurus alexandri juveniles could be feed-trained to accept commercial diets with gelatin in the total replacement of bovine heart in freshwater or salinity of $2 \mathrm{~g}$ of salt $\mathrm{L}^{-1}$.
\end{abstract}

Key words: carnivorous fish, feed training efficiency, management efficiency, neotropical fish.

\section{INTRODUCTION}

The production of carnivorous fish is lower than the production of omnivorous fish species, which can be explained by the high cannibalism rate. Due to this, it is necessary to perform the feed training of these species (Cyrino and Kubitza 2003). Various feed training techniques have been studied, emphasizing the gradual transition of ingredients

Correspondence to: Ana Lucia Salaro

E-mail: salaro@ufv.br
(Kubitza and Lovshin 1997, Kasai et al. 2011, Luz et al. 2011). This transition constitutes in the replacement of the moist ingredients (normally bovine heart) for dry diet. However, this technique has some disadvantages, such as the preparation and storage of the diets, and the instability of the pellets, which impairs water quality (Aubin et al. 2009). Thus, is a need to find alternatives for the product normally used as moist ingredient.

Commercial gelatin has been mixed with commercial diets during the feed training of 
carnivorous fish, but only empirically by fish farmers in the production of "surubins" (Pseudoplatystoma sp.). The use of gelatin showed promising results when used in the feed training of juvenile Hoplias lacerdae (Salaro et al. 2012a).

Another management used in fish production is the salinization of water (Fashina-Bombata and Busari 2003, Luz and Santos 2010). For some species of tropical freshwater, low salinity water ( 2 to $4 \mathrm{~g}$ of salt $\mathrm{L}^{-1}$ ) can be beneficial for the survival and growth of fish. The salinity of the water stimulates feeding and reduces the metabolic rate and feed conversion rate (Altinok and Grizzle 2001, Luz et al. 2008), in addition to decreasing the energy expenditure with the osmoregulation of animals (Altinok and Grizzle 2001, Boeuf and Payan 2001).

The "pacamã" Lophiosilurus alexandri, is a carnivorous species, of nocturnal habit and easy handling (Tenório et al. 2006). It can reach over $8 \mathrm{~kg}$ in nature. This species has been used in restocking programs of the São Francisco River (GuimarãesCruz et al. 2009). Lophiosilurus alexandri has a firm meat, absence of intramuscular bones and is much appreciated by the culinary sector. Previous studies have demonstrated the positive effect of salinity on larval breeding of this species, when using Artemia nauplii in the feeding (Luz and Santos 2008a, Santos and Luz 2009), which indicates the need for further study on water salinity in the remaining stages of the production of this species.

The objective of this study was to evaluate commercial gelatin in the total replacement of bovine heart in the feed training of Lophiosilurus alexandri in different water salinities.

\section{MATERIALS AND METHODS}

This experiment was approved by the Ethics Committee of Department of Animal Science, UFV (Protocol N 19/2014).

\section{EXPERIMENTAL DESIGN AND FISH GROWTH}

After absorption of the yolk sac, the Lophiosilurus alexandri larvae were kept in freshwater and fed with Artemia nauplii for a period of 30 days. After this period, the juveniles with standard length of $2.39 \pm 0.08 \mathrm{~cm}$ and weight of $0.20 \pm 0.03 \mathrm{~g}$ were stocked $\left(5\right.$ fish $\left.\mathrm{L}^{-1}\right)$ in 18 aquariums $(35 \times 30 \times 14$ $\mathrm{cm})$ containing five liters of water, a biological filter, constant aeration and controlled temperature $\left(27.0 \pm 1.0^{\circ} \mathrm{C}\right)$ through the use of a heater and thermostat. The aquariums were covered with a screen of $2 \mathrm{~mm}$ in diameter to prevent fish from escaping. The aquariums were kept in a $12 \mathrm{~h}$ of photophase by fluorescent lamps $(60 \mathrm{~W})$.

A completely randomized experimental design, in a $2 \times 3$ factorial arrangement was performed using two types of moist ingredients (bovine heart and gelatin) and three water salinities $(0.0 ; 2.0$ and 4.0 $\mathrm{g}$ of salt $\left.\mathrm{L}^{-1}\right)$ with three replications. A commercial common salt (Cisne ${ }^{\circledR}$, Brazilian Industry $-390 \mathrm{mg}$ sodium $\mathrm{g}^{-1}$ of salt, $25 \mu \mathrm{g}$ iodine $\mathrm{g} \mathrm{salt}^{-1}$ ) was used to create the different salinities. The salt was dissolved in the water of the aquariums prior to distribution of the fish. The fish were transferred directly from freshwater to the different salinity waters.

The fish were conditioned to accept commercial diets by the technique of gradual transition of ingredients in accordance to Salaro et al. (2012a), with modifications to the transition time of the last diet. The diets were made using commercial diets $(41.0 \%$ crude protein, $8.0 \%$ ether extract, $9.5 \%$ ash, $4490.0 \mathrm{kcal} \mathrm{kg}^{-1}$ gross energy) as dry ingredients and bovine heart or commercial gelatin powder (Gelita $\left.{ }^{\circledR}\right)$ as moist ingredients. The gelatin was dissolved in water at $50{ }^{\circ} \mathrm{C}$ and mixed with ration powder in accordance to Salaro et al. (2012a) (Table I). All diets were stored in a freezer $\left(-18^{\circ} \mathrm{C}\right)$ and thawed daily to make the pellets $(1$ $\mathrm{mm})$ just before the feeding of the fish.

The chemical composition of feed ingredients (Table II) was analyzed following the Association 
of Official Analytical Chemists methods (AOAC 1999). The crude protein (total nitrogen 6.25) was measured using the Kjeldahl method after acid digestion. The total lipids content was estimated using the Soxhlet apparatus method. The moisture was determined by drying the sample at $105^{\circ} \mathrm{C}$ for
$24 \mathrm{~h}$ to a constant weight. The ash was determined by incinerating the dried sample in a muffle furnace at $550{ }^{\circ} \mathrm{C}$ for $12 \mathrm{~h}$. These analyses were performed in the Food Analysis Laboratory, Department of Animal Science, Federal University of Viçosa, Brazil.

TABLE I

Quantity of ingredients and number of days of the diets used in the feed training of Lophiosilurus alexandri juveniles.

\begin{tabular}{ccccccc}
\hline Diets & & Diet 1 & Diet 2 & Diet 3 & Diet 4 & Diet 5 \\
\hline Time (days) & & 6 & 4 & 4 & 4 & 4 \\
\hline Treatments & Ingredients $\left(\mathrm{g} \mathrm{kg}^{-1}\right)$ & & & & & \\
\hline \multirow{2}{*}{ Bovine heart } & Commercial ration & 200.00 & 400.00 & 600.00 & 800.00 & 1000.00 \\
& Bovine heart & 800.00 & 600.00 & 400.00 & 200.00 & - \\
\hline \multirow{3}{*}{ Gelatin } & Commercial ration & 333.33 & 436.66 & 571.11 & 750.00 & 1000.00 \\
& Gelatin & 222.22 & 186.66 & 142.22 & 83.33 & - \\
& Water & 444.44 & 376.66 & 286.66 & 166.66 & - \\
\hline
\end{tabular}

TABLE II

Calculated chemical composition ( $\mathrm{g} \mathrm{kg}^{-1}$ dry matter) of diets used in feed training of Lophiosilurus alexandri.

\begin{tabular}{cccccc}
\hline Treatments & Diets & Dried Matter & Crude Protein & Ether extract & Ash \\
\hline \multirow{6}{*}{ Bovine heart } & Diet 1 & 359.06 & 772.76 & 81.08 & 50.17 \\
& Diet 2 & 480.02 & 703.01 & 83.62 & 65.48 \\
& Diet 3 & 600.98 & 633.26 & 86.15 & 80.78 \\
& Diet 4 & 721.94 & 563.52 & 88.69 & 96.09 \\
& Diet 5 & 842.90 & 493.77 & 91.23 & 111.40 \\
\hline \multirow{6}{*}{ Gelatin } & Diet 1 & 492.36 & 384.53 & 30.41 & 39.37 \\
& Diet 2 & 545.56 & 400.30 & 39.83 & 50.52 \\
& Diet 3 & 616.68 & 422.76 & 52.10 & 65.06 \\
& Diet 4 & 711.43 & 452.79 & 68.42 & 84.39 \\
& Diet 5 & 842.90 & 493.77 & 91.23 & 111.40 \\
\hline
\end{tabular}

The Lophiosilurus alexandri juveniles were hand fed to apparent satiety, three times a daily, at 08:00, 13:00 and 18:00 h. During the feeding of the fish, the aquariums were verified and the dead fish were removed and quantified. Every day, at 18:30 $\mathrm{h}, 100 \%$ of the water volume of each aquarium was changed. During this procedure, which lasted about $30 \mathrm{sec}$, juveniles were caught with a net and immediately transferred into another clean aquarium under the same experimental conditions (temperature and salinity water). This procedure is routine in the feed training of carnivorous fish in the Fish Nutrition Laboratory of the Department of Animal Biology of the Federal University of Viçosa. This management is performed with the aim of maintaining water quality due to the characteristics of the ingredients used in feed training. The water oxygen concentration was maintained above 6.50 
$\pm 1.0 \mathrm{mg} \mathrm{L}^{-1}$ by a supplemental aeration system. The $\mathrm{pH}$ was $8.10 \pm 0.56$ and the total ammonia was lower than $0.02 \mathrm{mg} \mathrm{L}^{-1}$. Water parameters were measured with Multiparameter Meter (model HI 9828, Hanna Instruments, Brazil).

\section{BIOMETRIC INDEX}

At the end of the experiment (36 days), all fish were counted, weighed on a precision scale (model MB45 Toledo ${ }^{\circledR} 0.001 \mathrm{~g}$ ) and their standard lengths were measured with a digital caliper (model series 500 Absolute Coolant Proof ${ }^{\circledR}$ of $0.0001 \mathrm{~m}$ ) for the calculation of weight gain (WG), length gain (LG), specific growth rate (SGR), survival rate (SR), the feed training efficiency (FTE), and the management efficiency (ME).

Specific growth rate (SGR) of fish were calculated according to the expression: $\mathrm{SGR}=$ $100 \times(\ln \mathrm{Wf}-\ln \mathrm{Wi}) / \Delta \mathrm{t}$, where $\mathrm{Wi}$ and $\mathrm{Wf}$ are the initial and final weights (in grams). The feed training efficiency (FTE) was calculated following the expression: FTE $=$ NCF/NLF $x$ 100, where $\mathrm{NCF}=$ number of conditioned fish (fish with body weight $20 \%$ greater than the initial average weight) and NLF $=$ number of live fish. The management efficiency (ME) was calculated following the expression: $\mathrm{ME}=\mathrm{FTE} \times \mathrm{SR} / 100$.

\section{STATISTICAL ANALYSES}

Data were analyzed using Factorial Anova, and means were compared by SNK test, at 5\% significance. The percentage results were arcsine transformed but only the percent results are presented.

\section{RESULTS}

No differences were observed between the moist ingredients (bovine heart or gelatin), water salinities and the interaction between them $(\mathrm{P}>$ 0.05 ) for weight gain, length gain and specific growth rate. The feed training efficiency was better for the fish conditioned with gelatin $(\mathrm{P}<0.05)$.
Salinity effects were observed on survival rate and the management efficiency $(\mathrm{P}<0.05)$, the lower rates of both parameters were verified at $4 \mathrm{~g}$ of salt $\mathrm{L}^{-1}$ (Table III).

\section{DISCUSSION}

The lack of difference in weight and length gains and the specific growth rate of fish, using gelatin as a replacement of bovine heart, can probably be explained by the greater stability of the pellets on the water, facilitating the seizure and intake of food by fish. These results show the possibility of using gelatin as a moist ingredient in feed training of Lophiosilurus alexandri as found by Hoplias lacerdae (Salaro et al. 2012a). Thus, studies using gelatin for others carnivorous species should be performed.

The best feed training efficiency of fish, achieved by those fed diets containing gelatin, indicates the good palatability of these diets for Lophiosilurus alexandri. However, for Hoplias lacerdae, the use of gelatin afforded lower feed training efficiency than that observed with bovine heart, requiring supplementation with fish meal to obtain the feed training efficiency equivalent to diets with bovine heart (Salaro et al. 2012a). These results reinforce that palatability of the diet is species-specific (Kasumyan and Tinkova 2013).

The lower survival rate of fish in salinity $4 \mathrm{~g}$ of salt $\mathrm{L}^{-1}$ may be related to the development phase of the animals (Fashina-Bombata and Busari 2003) and the time of exposure to water salinity. Larvae of Lophiosilurus alexandri with 12 days of age support salinity up to $6 \mathrm{~g}$ of salt $\mathrm{L}^{-1}$ for $96 \mathrm{~h}$ (Luz and Santos 2008b). It is possible that the lower survival rate is also associated with stress related to constant changes in diets (Barcellos et al. 2000) and the daily changes of water aquariums (Salaro et al. 2012b). Fish more susceptible to stress are less well suited to tolerate multiple stressors and require a long time period to adapt to saline water (Fevolden et al. 2003). 
TABLE III

P values and average $( \pm$ SD) of survival rate (SR), weight gain (WG), length gain (LG), specific growth rate (SGR), feed training efficiency (FTE) and efficiency of management (EM) of juveniles of Lophiosilurus alexandri to feed training with two moist ingredients (bovine heart or gelatin) and three water salinities, for a total of 36 days of experiment.

\begin{tabular}{|c|c|c|c|c|c|c|}
\hline \multirow[t]{2}{*}{ Statistical } & \multicolumn{6}{|c|}{$\mathrm{P}$ values } \\
\hline & $\begin{array}{l}\text { SR } \\
(\%)\end{array}$ & $\begin{array}{l}\text { WG } \\
(\mathrm{g})\end{array}$ & $\begin{array}{c}\mathrm{LG} \\
(\mathrm{cm})\end{array}$ & $\begin{array}{c}\text { SGR } \\
\left(\% \text { day }^{-1}\right)\end{array}$ & $\begin{array}{l}\text { FTE } \\
(\%)\end{array}$ & $\begin{array}{l}\text { EM } \\
(\%)\end{array}$ \\
\hline $\begin{array}{l}\text { Salinity } \\
\text { (S) }\end{array}$ & 0.0001 & Ns & Ns & Ns & Ns & 0.0003 \\
\hline $\begin{array}{l}\text { Ingredient } \\
\text { (I) }\end{array}$ & Ns & Ns & Ns & Ns & 0.0471 & Ns \\
\hline $\begin{array}{l}\text { Interaction } \\
\quad \mathrm{S} \times \mathrm{I}\end{array}$ & Ns & Ns & Ns & Ns & Ns & Ns \\
\hline Salinity & \multicolumn{6}{|c|}{ Means } \\
\hline $0 \mathrm{~g}$ of salt $\mathrm{L}^{-1}$ & $88.6 \pm 9.2^{\mathrm{A}}$ & $0.5 \pm 0.2$ & $1.2 \pm 0.3$ & $3.6 \pm 0.7$ & $98.3 \pm 2.5$ & $87.3 \pm 10.5^{\mathrm{A}}$ \\
\hline $2 \mathrm{~g}$ of salt $\mathrm{L}^{-1}$ & $82.0 \pm 5.5^{\mathrm{A}}$ & $0.4 \pm 0.2$ & $1.0 \pm 0.3$ & $3.2 \pm 0.9$ & $99.1 \pm 2.0$ & $81.3 \pm 6.0^{\mathrm{A}}$ \\
\hline $4 \mathrm{~g}$ of salt $\mathrm{L}^{-1}$ & $58.6 \pm 12.0^{\mathrm{B}}$ & $0.6 \pm 0.3$ & $1.1 \pm 0.4$ & $3.7 \pm 1.1$ & $98.8 \pm 2.7$ & $58.0 \pm 12.0^{\mathrm{B}}$ \\
\hline Ingredient & \multicolumn{6}{|c|}{ Means } \\
\hline Bovine heart & $78.2 \pm 10.9$ & $0.5 \pm 0.2$ & $1.1 \pm 0.3$ & $3.5 \pm 0.9$ & $97.6 \pm 2.9^{\mathrm{B}}$ & $76.4 \pm 11.5$ \\
\hline Gelatin & $74.6 \pm 20.2$ & $0.5 \pm 0.2$ & $1.1 \pm 0.4$ & $3.5 \pm 0.9$ & $100.0 \pm 0.0^{\mathrm{A}}$ & $74.6 \pm 20.2$ \\
\hline $\mathrm{CV}$ & 11.0 & 50.1 & 38.8 & 28.8 & 2.3 & 12.1 \\
\hline
\end{tabular}

Means followed by the same capital letters in the column did not differ by Student-NewmanKeuls test $(\mathrm{P}<0.05)$. Ns - not significant.

In the larviculture of freshwater fish as Lophiosilurus alexandri (Luz and Santos 2008b), Pseudoplatystoma corruscans (Santos and Luz 2009) and Pimelodus maculatus (Weingartner and Zaniboni Filho 2004), 2 g of salt $\mathrm{L}^{-1}$ can be used, whereas larvae of Prochilodus costatus (Santos and Luz 2009), Piaractus mesopatamiscus (Jomori et al. 2012) and Hoplias lacerdae (Luz and Portella 2002) can be reared at $4 \mathrm{~g}$ of salt $\mathrm{L}^{-1}$. Furthermore, $6 \mathrm{~g}$ of salt $\mathrm{L}^{-1}$ was tolerated by Rhinelepis aspera during the larviculture (Luz and Santos 2010), showing different salinity tolerances among different fish species.

The lower survival rate could also be related to an osmotic imbalance of the fish at $4 \mathrm{~g}$ of salt $\mathrm{L}^{-1}$. The increasing salinity of the water can lead to a number of metabolic and physiological changes (Boeuf and Payan 2001, Luz et al. 2008). This fact was also previously observed for juvenile of
Hoplias lacerdae during feed training in different water salinities (Salaro et al. 2012b). However, the use of specific salinities can reduce stress and decrease susceptibility to diseases, as well as preserve and control pathogens (Altinok and Grizzle 2001, Garcia et al. 2007). For Hoplias lacerdae, salinity up to $5 \mathrm{~g}$ of salt $\mathrm{L}^{-1}$ attenuated stress during feed training (Salaro et al. 2012a).

In conclusion, Lophiosilurus alexandri juveniles can be feed-trained to accept commercial diets with gelatin as a replacement for bovine heart in freshwater or salinity of $2 \mathrm{~g}$ of salt $\mathrm{L}^{-1}$.

\section{ACKNOWLEDGMENTS}

We wish to thank the Conselho Nacional de Desenvolvimento Científico e Tecnológico (CNPq) and the Fundação de Amparo a Pesquisa do Estado de Minas Gerais (FAPEMIG), for providing financial support for this project. 


\section{RESUMO}

O objetivo deste estudo foi avaliar o uso de gelatina comercial em substituição total do coração bovino no condicionamento alimentar de pacamã Lophiosilurus alexandri em diferentes salinidades da água. $\mathrm{O}$ experimento foi realizado em delineamento inteiramente casualizado, em esquema fatorial $2 \times 3$, usando dois tipos de ingredientes úmidos (coração bovino e gelatina) e três salinidades da água $(0,0 ; 2,0$ e 4,0 g de sal L-1 $)$ com três repetições cada. Juvenis $(2,39 \pm 0,08 \mathrm{~cm}$ de comprimento padrão e 0,20 $\pm 0,03 \mathrm{~g}$ de peso) foram condicionados a aceitar dietas comerciais através da técnica da transição gradual de ingredientes. Após 36 dias de experimento não foram observadas diferenças significativas para o ganho de peso, ganho em comprimento e taxa de crescimento específico. A eficiência do condicionamento alimentar foi melhor $(\mathrm{P}<0,05)$ com o uso da gelatina $(100 \%)$. Houve efeito negativo da salinidade da água na sobrevivência e eficiência do manejo na concentração de $4 \mathrm{~g}$ de sal L- ${ }^{1}$, com valores de 58,6 $\pm 12,0 \%$ e 58,0 $\pm 12,0 \%$, respectivamente. Juvenis de Lophiosilurus alexandri podem ser condicionados a aceitar dietas comerciais com o emprego da gelatina em substituição total do coração bovino, em água doce ou na salinidade de 2 g de sal L- ${ }^{1}$.

Palavras-chave: peixe carnívoro, eficiência do condicionamento alimentar, eficiência do manejo, peixe neotropical.

\section{REFERENCES}

ALTINOK I AND GRIZZLE JM. 2001. Effects of brackish water on growth, feed conversion and energy absorption efficiency by juvenile euryhaline and freshwater stenohaline fishes. J Fish Biol 59: 1142-1152.

AOAC - ASSOCIATION OF OFFICIAL ANALYTICAL CHEMISTS. 1999. Official Methods of Analysis of Official Analytical Chemists International. $16^{\text {th }}$ ed., Association of Official Analytical Chemists Inc., Washington, DC, p. 1141.

AUBIN J, PAPATRYPHON E, VAN DER WERF HMG AND CHATZIFOTIS S. 2009. Assessment of the environmental impact of carnivorous finfish production systems using life cycle assessment. J Clean Prod 17: 354-361.

BArCellos LJG, SOUZA SMG AND WOEHL VM. 2000. Estresse em peixes: fisiologia da resposta ao estresse, causas e consequências. Bol Inst Pesca 26: 99-111.

BOEUF G AND PAYAN P. 2001. How should salinity influence fish growth? Comp Biochem Physiol 130: 411-423.
CYRINO JEP AND KUBITZA F. 2003. Diets for feed training peacock bass Cichla sp. Sci Agric 60: 609-613.

FASHINA-BOMBATA HA AND BUSARI AN. 2003. Influence of salinity on the developmental stages of African catfish Heterobranchus longifilis (Valenciennes, 1840). Aquacult 224: 213-222.

FEVOlden SE, Røed KH AND FJalestad K. 2003. A combined salt and confinement stress enhances mortality in rainbow trout (Oncorhynchus mykiss) selected for high stress responsiveness. Aquacult 216: 67-76.

GARCIA LO, BECKER AG, COPATTI CE AND BALDISSEROTO B. 2007. Salt in the food and water as a supportive therapy for Ichthyophthirius multifiliis infestation on Silver catfish, Rhamdia quelen, fingerlings. J World Aquacult Soc 38: $1-11$.

GuimarÃes-Cruz RJ, SANtos JE, SATO Y AND VElosoJÚNIOR VC. 2009. Early development stages of the catfish Lophiosilurus alexandri Steindachner, 1877 (Pisces: Pseudopimelodidae) from the São Francisco River basin, Brazil. J Appl Ichthyol 25: 321-327.

JOMORI RK, LUZ RK AND PORTELlA MC. 2012. Effect of Salinity on Larval Rearing of Pacu, Piaractus mesopotamicus, a Freshwater Species. J World Aquacult Soc 43: 423-432.

KASAI RYD, SALARO AL, ZUANON JAS, SABARENSE CM, TAVARES MM AND CAMPELO DAV. 2011. Training of trairão fingerlings fed with diets containing different levels of vitamin C. R Bras Zootec 40: 463-468.

KASUMYAN AO AND TINKOVA TV. 2013. Taste Attractiveness of Different Hydrobionts for Roach Rutilus rutilus, Bitterling Rhodeus sericeus amarus, and Rainbow Trout Oncorhynchus mykiss. J Ichthyol 53: 499-508.

KUBITZA F AND LOVSHIN LL. 1997. Effects of initial weight and genetic strain on feedtraining largemouth bass Micropterus salmoides using ground fish flesh and freeze dried krill as starter diets. Aquacult 148: 179-190.

LUZ RK, MARTíneZ-Álvarez RM, DE PEDRo N AND DELGADO MJ. 2008. Growth, food intake regulation and metabolic adaptations in goldfish (Carassius auratus) exposed to different salinities. Aquacult 276: 171-178.

LUZ RK AND PORTELLA MC. 2002. Larvicultura de trairão (Hoplias lacerdae) em água doce e água salinizada. R Bras Zootec 31: 829-834.

LUZ RK AND SANTOS JCE. 2008a. Densidade de estocagem e salinidade da água na larvicultura do pacamã. Pesq Agropec Bras 43: 903-909.

LUZ RK AND SANTOS JCE. 2008b. Avaliação da tolerância de larvas do pacamã Lophiosilurus alexandri Steindachner, 1877 (Pisces: Siluriformes) a diferentes salinidades. Acta Sci 30: 345-350.

LUZ RK AND SANTOS JCE. 2010. Effect of salt addition and feeding frequency on cascudo preto Rhinelepis aspera (Pisces: Loricariidae) larviculture. J Appl Ichthyol 26: 453-455. 
LUz RK, SANTOS JCE, PEDREIRA MM AND TEIXEIRA EA. 2011. Effect of water flow rate and feed training on "pacamã" (Siluriforme: Pseudopimelodidae) juvenile production. Arq Bras Med Vet Zootec 63: 973-979.

SAlaro AL, CAMPElo DAV, PONTES MD, TAVARES MM, ZUANON JAS AND LUZ RK. 2012b. Saline water for juvenile giant trahira during feed training. R Bras Zootec 41: $1342-1345$.

SALARO AL, OLIVEIRA JR JC, PONTES MD, OLIVEIRA KRB, NEVES IGAA, FERRAZ RB, HISANO H AND ZUANON JAS. 2012a. Replacement of moist ingredients in the feed training of carnivorous fish. R Bras Zootec 41: 2294-2298.
SANTOS JCE AND LUZ RK. 2009. Effect of salinity and prey concentrations on Pseudoplatystoma corruscans, Prochilodus costatus and Lophiosilurus alexandri larviculture. Aquacult 287: 324-328.

TENÓRIO RA, SANTOS AJG, LOPES JP AND NOGUEIRA SEM. 2006. Crescimento do niquim (Lophiosilurus alexandri Steindachner 1876), em diferentes condições de luminosidade e tipos de alimentos. Acta Sci Boil Sci 28: 305-309.

WEINGARTNER M AND ZANIBONI FILHO E. 2004. Efeito de fatores abióticos na larvicultura de pintado amarelo Pimelodus maculatus (Lacépède, 1803): salinidade e cor de tanque. Acta Sci 26: 151-157. 
